\author{
Н.С. Седых
}

\title{
МЕДИАДИСКУРС О ТЕРРОРИЗМЕ: СОЦИАЛЬНЫЕ И ПСИХОЛИНГВИСТИЧЕСКИЕ АСПЕКТЫ
}

\begin{abstract}
Аннотация. В статье рассматриваются ключевые черты терроризма, раскрывающие сущность этого явления в контексте глобализации современных индормационных рисков, угроз и вызовов. Приводятся результаты лингвистических исследований, экспертиз публицистического и медиадискурса о терроризме и анализируются практики использования слов «терроризм», “террорист», «терроризировать» как в прямом, так и переносном значении. В этой связи актуализируются вопросы трансформации обыденного сознания под воздействием соответствующих медиадискурсивных практик. Обсуждаются некоторые следствия и последствия "дискурсивного давления» и «информационной агрессивности» Анализируются социальные репрезентации терроризма в обыденном сознании, приводятся результаты эмпирического исследования автора с целью изучения представлений о субъектах терроризма (террористах-лидерах, исполнителях, смертниках-мужчинах и женщинах) у студенческой молодёжи Южно-российского региона. Обобщаются и сопоставляются данные, делаются выводы о психологических последствиях террористической агрессии, их пролонгированном воздействии на индивидуальное и общественное сознание. В заключении акцентируется внимание на необходимости активизации информационного антитерроризма, развитии социальных, психолингвистических и информационно-коммуникационных практик противодействия идеологии экстремизма и формировании антитеррористических ценностей в российском обществе.
\end{abstract}

Ключевые слова: общество, терроризм, информация, массовая коммуникация, сочиальные представления, дискурс, медиадискурс, обыденное сознание, воздействие, противодействие.

H есомненно, в условиях глобальной информатизации социального пространства феномен терроризма требует осмысления в контексте особенностей развития массовой коммуникации. Современный терроризм, с точки зрения автора данной статьи, является способом информационно-психологического воздействия с целью управления социумом посредством превентивного устрашения и достижения социально-политических и экономических целей. Террористическая агрессия социально-нормированный коммуникативный акт, имеющий в рамках конкретной и дискретной ситуации деструктивную цель и призванный решить опредёлённые задачи ${ }^{1}$. Исходя из такого понимания природы современного терроризма, считаем целесообразным изучение соответствующего дискурса масс-медиа, его трансформаций, социальных практик и психологических акцен-

1 Седых Н.С. Современный терроризм с точки зрения информационно-психологических угроз // Национальная безопасность. 2012. № 2 (19). С. 69. тов, скрыто или явно присутствующие при описании реальных событий.

Важно отметить, что в конце XX века начинает достаточно активно развиваться дискурсивная психология, которая основывается на пересмотре принципиальных идей когнитивной и социальной психологии ${ }^{2}$ В рамках данной исследовательской парадигмы, дискурс определяется как репертуар интерпретаций - то есть как совокупность наборов возможных последовательностей высказываний в конкретных ситуативных, временных, культурных и институциональных рамках. Вместе с тем психика субъекта рассматривается не как совокупность изолированных когнитивных феноменов (сознание, мышление, восприятие, память и т.д.), а как сложное единство динамичных языковых конструктов, приобретающих значение в процессах интеракции в рамках определенных дискурсов. При этом сам субъект мыслится не как сущность изолированных внутренних процессов, для кото-

\footnotetext{
2 Чернов А.Ю. Качественный подход в психологическом исследовании. Волгоград, 2008. 340 с.
} 
рого язык является лишь средством передачи неких разделяемых смыслов; дискурсивная психология рассматривает субъекта через призму языка, дискурса и социальной практики ${ }^{3}$.

Дискурс одновременно является и результатом конструирования и инструментом конструирования социальной реальности. В силу этого дискурс, по мнению Т. ванн Дейка, “существенная составляющая социокультурного взаимодействия" ${ }^{4}$. В этой связи принципиальной нам представляется идея о том, что «дискурсы не отражают какой-то абстрактный внешний мир, находящийся «вне» или «за пределами» человека», а скорее «создают мир, который выглядит реальным или истинным для говорящего субъекта ${ }^{5}$. Интересно, что скандинавские исследователи М. Йоргенсен и Л. Филлипс трактуют дискурс в терминах способности конструирования проживаемой нами реальности ${ }^{6}$. Теоретики дискурсивной психологии Поттер и Уэзерелл рассматривают дискурс как «репертуар интерпретации»7. Причём это понятие вводится с целью выделить особую динамическую изменчивую природу дискурса. Отметим, что любой дискурс включает различные языковые и неязыковые стратегии и практики, цель которых продуцирование определённого вида информации, её рецепцию и интерпретацию ${ }^{8}$.

Медиадискур рассматривается как тематически сфокусированная, социокультурно обусловленная речемыслительная деятельность в массмедийном пространстве. Центральным предметом медиадискурса являются способы описания какихлибо явлений и процессов и передачи знания о них. В этом отношении, как указывает Е.А. Кожемякин медиадискурс является в высшей степени посреднической деятельностью. Это обусловлено тем, что информация конвертируется в смыслы и происходит конструирование знания. Медиадискурс осуществляет перевод знания с одного уровня, например, институционального, на другой, напри-

\footnotetext{
3 Макаров М.Л. Основы теории дискурса. М., 2003. 280 с.

4 Дейк ван Т. Язык. Познание. Коммуникация. М., 1989. 308 с.

5 Филипс Л.Дж., Йоргенсен М.В. Дискурс-анализ. Теория и метод. Харьков, 2004. 336 с.

6 Там же.

7 Поттер Дж., Уэзерелл М. Дискурс и субъект (http://www. psylib.ukrweb.net/books/_pottu01.htm).

8 Черкасова М.Н. Речевые формы агрессии в текстах СМИ. Ростов-на-Дону, 2011. 123 с.
}

мер, обыденный. Однако знание такого рода имеет относительный характер, так как его «истинность» или «значимость» определяется лингвосоциальным, социокультурным и - шире - историко-цивилизационным контекстами, учёт которых также необходим при описании медиадискурса9.

Отметим, что неотъемлемой частью публицистического дискурса сегодня, как считают эксперты-аналитики, становится «лингвистика убеждения». Поэтому современные исследователи оперируют такими понятиями как «давление дискурса», «дискурсивная доминанта». Понятие медиадискурса, как отмечает М.Н. Черкасова, шире понятия «публицистический дискурс». Однако доминанты этих дискурсов совпадают и находят своё выражение в социальной оценочности. При этом «речь идёт об акцентах в системе ценностей, аксиологии (обобщенных устойчивых представлениях о значимых предметах и событиях окружающего мира) медиадискурса, то есть об условной шкале оценки в определённой системе координат, которое находит своё материальное выражение в презентации явления, события, образа в медиатексте» ${ }^{10}$.

Так, анализируя номинации террористовсмертников в российских СМИ, М.Н. Черкасова отмечает, что, начиная с 2009-2010 гг. доминируют такие, как «шахидка» / «шахид»; «смертник»/ «смертница», «живые бомбы», «бомбистки». Эти номинации постепенно вытесняют иноязычное «камикадзе», распространённое в печати в последнее десятилетие XX века. Автор связывает это, прежде всего, «с политико-социальной ситуацией, когда необходимо чётко зафиксировать номинации явления без дополнительных созначений и нежелательных ассоциаций» ${ }^{11}$. Происхождение слова «камикадзе» имеет романтический ореол и в переводе с японского означает «божественный ветер», который, как гласит легенда, разметал в XIII веке вражеский флот у берегов Японии. В современном русском языковом пространстве камикадзе - это «самоубийца вообще, причём речь идёт как об осознанном суициде, так и о несчастном случае». В силу этого слово «камикадзе», «из-за своей ассимиляции и расширения семантического объёма са-

\footnotetext{
9 Кожемякин Е.А. Дискурс-анализ массовой коммуникации (http://www.gmj.sfedu.ru/v2i1/v2i1_kozhemyakin.htm).

10 Черкасова М.Н. Речевые формы агрессии в текстах СМИ. Ростов-на-Дону, 2011. С. 48-49.

11 Там же. С. 50.
} 


\section{Социальные страсти}

мой лексической единицы не имеет такую «агрессивную» нагрузку, как слово «террорист»» ${ }^{12}$.

Вместе с тем М.Н. Черкасова обращает внимание на важную тенденцию употребления в рамках публицистического дискурса слова «террорист» в переносном значении, которое в данном качество означает - «чрезмерную жестокость, запугивание, преследование кого-либо» ${ }^{13}$. В частности, в качестве примера наряду с другими, приводится, что «А.Б. Пугачёва, называет бывшего зятя «террористом» в контексте семейного конфликта: «0н ведёт себя как террорист!»» ${ }^{14}$. Такие примеры присутствуют и в обыденной речи. Автору данной статьи приходилось, например, слышать в живой разговорной речи такое выражение: «он - смертник!», прозвучавшие в адрес студента, халатно относившегося к экзаменационной сессии. Вероятно, это во многом обусловлено тем, что «дискурс - прежде всего, это речь, погруженная в жизнь, в социальный контекст». Неслучайно Ж.-К. Коке называет дискурс «сцеплением структур значения, обладающих собственными правилами комбинации и трансформации» ${ }^{15}$. Это иллюстрируется и тем, что в информационном пространстве, причём в текстах, не связанных с терактами, многочисленны и переносные употребления глагола «терроризировать» ${ }^{16}$. Подобных примеров, как известно, немало и в обыденной речи. Так, автору довелось услышать на одном из совещаний слова руководителя, который требовал от сотрудников исполнения распоряжения, заявив: «Я буду вас терроризировать!».

Такой дискурсивный поворот с нашей точки зрения свидетельствует: понятие «терроризм» зафиксировалось на уровне обыденного сознания как норма сегодняшней жизни. Заметим, что обыденное сознание - совокупность представлений, знаний, установок и стереотипов, основывающихся на непосредственном повседневном опыте людей и доминирующих в социальной общности, которой

\section{2 Там же. С. 50.}

13 Современный словарь иностранных слов / Сост. М.Н. Черкасова, Л.Н. Черкасова. Ростов-на-Дону, 2009. 256 с.

14 Цит. по: Черкасова М.Н. Речевые формы агрессии в текстах СМИ. Ростов-на-Дону, 2011. С. 50.

15 Цит. по: Ильин И. Постмодернизм. Словари терминов (http://terme.ru/dictionary/179/word/diskurs).

16 Черкасова М.Н. Речевые формы агрессии в текстах СМИ. Ростов-на-Дону, 2011. С. 50. они принадлежат ${ }^{17}$. Реальность повседневной жизни имеет интерсубъективный характер, поэтому в процессе коммуникации, её элементы обозначаются, называются и наделяются определёнными свойствами. В то же время социальные формы общения участвуют в процессах интериоризации. Интериориза́ция (от фр. intériorisation - переход извне внутрь и лат. interior - внутренний) - формирование внутренних структур человеческой психики посредством усвоения внешней социальной деятельности, присвоения жизненного опыта, становления психических функций и развития в целом. Подчеркнём, что вследствие интериоризации психика человека приобретает способность оперировать образами предметов, которые в данный момент отсутствуют в его поле зрения ${ }^{18}$.

Итак, в результате воздействий массовой и, как следствие, межличностной коммуникации понятие «терроризм» подвергается интериоризации и «вписывается» в картину мира человека, которая определяет специфический способ восприятия и интерпретации событий и явлений. Картина мира является подвижной структурой и соотносится с образом мира, который более устойчив. Структурой, являющейся одновременно регулятором и строительным материалом образа мира, является структура субъективного опыта. В эту структуру входят три слоя - «перцептивный мир», который соотносится с поверхностными структурами образа мира. Следующий слой - семантический выражен многомерными отношениями, возникающими под воздействием сенсорно-перцептивного, представленного, мыслительного следов деятельности. И наиболее глубокий и устойчивый слой - слой амодальных структур образуется при обработке «семантического слоя». Важно отметить, что в картине мира смысловые образования выполняют основные функции: репрезентативную (представление жизненного мира субъекту), интерпретативную (структурирование, интерпретация жизненных явлений и событий), регулятивную (регуляция поведения человека в жизненных ситуациях $)^{19}$.

Соответственно, осмысление событий повседневности, в которые во многом в силу глобализа-

\footnotetext{
17 См.: Психологический словарь (http://psychology.net.ru/ dictionaries/psy.html?word=586).

18 Интериоризация (http://ru.wikipedia.org/wiki/).

19 См.: Чешуева Н.А. Понятие «образ мира» в психологической науки // Вестник ТГПУ. 2007. № 10 (73). С. 20-23.
} 
ции массовой коммуникации включились события, связанные с терроризмом и его различными проявлениями, находит отражение в картине мира, обыденном языке и разговорной речи. Подчеркнём, что язык является психолингвистической структурой. Посредством использования языка в качестве репрезентативной системы, люди создают модель собственного опыта. И вместе с тем язык используется для того, чтобы передать данную модель, или репрезентацию мира другим. Процесс передачи может иметь различные, как устные, так и письменные формы. Однако написанные и сказанные слова являются «поверхностными структурами». Они в свою очередь представляют собой преобразованные психические и лингвистические «глубинные структуры» Итак, слова могут одновременно отражать и формировать психический опыт, что делает их мощным орудием, так как позволяет влиять на сознательные или бессознательные психические процессы с помощью языковых средств ${ }^{20}$.

Причём, особенно ярко, на наш взгляд, это проявляется в условиях глобальной информатизации. Современные СМИ не столько отражают действительность, сколько посредством «интерпретаций, комментариев, оценок способствуют созданию идеологического фона» ${ }^{21}$. Это позволяет констатировать развитие «информационной агрессивности», под которой, следует подразумевать «навязывание определённых стереотипов, мнений, суждений, моделей поведения и т.д. только в одностороннем порядке» ${ }^{22}$.

Необходимо подчеркнуть, что массовая коммуникация сегодня выступает не только в качестве мощной социальной силы, но и, по мнению Ж. Бодрийяра, в качестве творца новой «гиперреальности» ${ }^{23}$. Ю. Хабермас, разрабатывая свою теорию коммуникативного действия, рассматривает коммуникацию в качестве базового социального процесса. С его точки зрения, язык является средой господства и социальной власти, поэтому представляет собой вид «метаинституции, от которой зависят все общественные институты». При

20 См.: Браун Дж. Психология Фрейда и постфрейдисты. M., 1997. C. 25-28.

21 Клушина Н.И. Стилистика публицистического текста. M., 2008. 244 c.

22 Черкасова М.Н. Речевые формы агрессии в текстах СМИ. Ростов-на-Дону, 2011. С. 61.

23 Бодрийяр Ж. Общество потребления. Его мифы и структуры / Пер с фр. и примеч. Е.А. Самарской. М., 2006. 269 с. этом он подчёркивает, что метаинституция языка как традиция в свою очередь зависит от общественных процессов. Обращаясь к коммуникации как к повседневной практике частных жизненных миров, Ю. Хабермас полагает процессы коммуникативной рационализации жизненных миров в качестве структурирующих общественность ${ }^{24}$. Как известно, бурное развитие информационной сферы современного общества повлекло за собой ряд социальных последствий, которые оцениваются весьма неоднозначно. Это во многом определяется тем, что информационное пространство, как полагает современный исследователь А.В. Мирошниченко, выступает как среда, имеющая в своей основе ценности, цели, перспективы и т.д. ${ }^{25}$.

Информационно пространство сегодня, по мнению автора данной статьи, становится одновременно пространством социального познания и конструирования феномена терроризма. Конструирование рассматривается как приведение в систему информации о мире, организация этой информации в связные структуры с целью постижения ее смысла. В результате создаётся образ социального мира, который предстает перед человеком как определенная социальная реальность $^{26}$. При рассмотрении этого процесса в контексте информационных воздействий, на наш взгляд, следует опираться на понятие «конструкт» в постпозитивистском контексте, которое трактуется как целенаправленное формулирование значений посредством таких ментальных процессов, как структурирование, концептуализация, интерпретация и анализ. Конструировать, с этой точки зрения, - значит интроспективно выявлять значение событий на основании прецедентов ${ }^{27}$. В этой связи подчеркнём, что человек, согласно постулатам постклассической психологии, понимается как сложная, открытая самоорганизующаяся система.

\footnotetext{
24 Хабермас Ю. Моральное сознание и коммуникативное действие / Пер. с нем. под ред. Д.В. Скляднева, послесл. Б.В. Маркова. СПб., 2000. 157 с.

25 Мирошниченко А.В. Психологические аспекты информационной безопасности. Терроризм как угроза информационной безопасности страны // Сборник статей международной научно-практической конференции. Ч. 6. Уфа, 2014. C. $210-211$.

26 Андреева Г.М. Психология социального познания. М., 2004. 288 c.

27 Чернов А.Ю. Качественный подход в психологическом исследовании. Волгоград, 2008. 340 с.
} 


\section{Социальные страсти}

С точки зрения теории психологических систем психическое трактуется как то, что порождается, возникает в процессе функционирования психологических систем и тем самым обеспечивает их самоорганизацию и саморазвитие. Безусловно, сегодня информационные потоки организуют процесс социального познания и влияют на порождение особой психологической онтологии «представляющей собой системный конструкт, который опосредует взаимоотношения между человеком и миром «чистой» объективности («амодальным миром»), что и обеспечивает превращение амодального мира в «освоенную» человеком и ставшую его индивидуальной характеристикой действительность» ${ }^{28}$.

Итак, очевидно, что современная массовая коммуникация оказывает непосредственное воздействие на развитие человека как психологической системы, в которую включены субъективная (образ мира) и деятельностная компоненты (образ жизни). Соответственно, транслируемая масс-медиа информация о террористических проявлениях трансформирует образ мира человека и воспринимается как часть действительности. При этом мы исходим из понимания действительности как многомерного мира человека, а образа мира как целостной и системно-смысловой действительности, представляющей собой мир данного человека, в котором он живет и действует ${ }^{29}$.

В этой связи необходимо обратиться к вопросам познания социальных объектов, ситуаций в условиях глобальной информатизации. Социальное познание определяется, прежде всего, процессами коммуникации, так как оно возникает и поддерживается социальным взаимодействием. Приоритетное значение принадлежит социальному контексту и среде. В данном случае имеется в виду языковая среда как символическая репрезентация окружающего мира. Отметим, что, Г.А. Андреева, указывает на разделяемость как ведущий признак социального познания, обусловленный тем, что люди существуют в некотором общем познавательном пространстве и в определённой степени разделяют значение тех или иных познаваемых ими объектов. Причём средством выработки таких разделяемых представлений, значений является

28 Клочнко В.Е., Галажинский Э.В. Самореализация личности: системный взгляд. Томск, 2004. 154 с.

29 Чешуева Н.А. Понятие «образ мира» в психологической науки // Вестник ТГПУ. 2007. № 10 (73). С. 20-23. коммуникация ${ }^{30}$. Итак, массовые коммуникации сегодня задают векторы социального познания феномена терроризма и определяют границы его конструирования.

В этой связи необходимо обратиться к результатам эмпирического исследования социальных представлений о терроризме, проведённых автором данной статьи. Необходимо подчеркнуть, что социальные представления, выполняют три основные функции. Во-первых, это функция инструмента познания, при этом роль социальных представлений аналогична роли обычных категорий, посредством которых индивид описывает, классифицирует, объясняет события. Во-вторых, это функция опосредования поведения, которая выражается в том, что социальные представления способствуют направлению коммуникаций в группе, обозначению ценностей, регулирующих поведение. В-третьих, это адаптационная функция, проявляющаяся в том, что социальные представления являются средством адаптации совершившихся событий к уже имеющимся, то есть способствуют сохранению сложившийся картины мира ${ }^{31}$.

Как свидетельствуют полученные нами данные, социальные представления о терроризме, развиваются под воздействием дискурсивных практик масс-медиа ${ }^{32}$. Это во многом обусловлено тем, что СМИ сегодня не только информируют население, но и выполняют конструирующую функцию, причём, особенно наглядно это проявляется, когда речь идёт о явлениях недоступных для непосредственного чувственного восприятия. Неслучайно в работах М. Фуко звучит термин «дискурсия», который понимается им как «сложная совокупность языковых практик, участвующих в формировании представлений о том объекте, который они подразумевают» ${ }^{33}$. Вместе с тем «представление, - считает исследователь В. Вагнер, - это концептуальный пирожок, сделанный из мира-теста силами дискурса, консенсуса и социального поведения» ${ }^{34}$. В свою очередь

30 Андреева Г.М. Психология социального познания. М., 2004. 288 c.

31 Там же.

32 Седых Н.С. Психология терроризма: Электронный учебник. Ростов-на-Дону: ЮФУ. (Объём 700 мгб. Регистрационное свидетельство № 34730).

33 Фуко М. Археология знания / Пер. с фр.; общ. ред. Бр. Левченко. К., 1996. 208 с.

34 Wagner W. Queries about social representation and construction // Journal for the theory of social behaviour. 1996. V. 26.2. P. 109. 
дискурсы представляют собой «динамическую деятельность, конструирующую смысл». Причём «...воображаемое получает, таким образом, совершенно реальное, материальное воплощение» ${ }^{35}$.

Медиадискурс о терроризме, на наш взгляд, относится к репрезентирующему типу. Это определяется тем, что в нём представляется терроризм как одна из значимых угроз современности, которая раскрывается посредством позиционирования в дискурсе масс - медиа конкретных персон, являющихся проводниками экстремисткой идеологии и их деятельности, её причин и последствий ${ }^{36}$.

Остановимся на результатах нашего исследования, отражающих особенности социальных представлений о субъектах терроризма, олицетворяющих собой угрозу безопасности жизни, здоровью и социальному благополучию. Основным инструментом данного исследования был метод семантического дифференциала (англ. semantic differential). Методика исследования разработана мною на базе современного русского языка и отражает сформировавшиеся в нашей культуре представления о внешнем облике, социально - демографическом статусе и структуре личности. Методика содержит 55 прилагательных, являющихся вербальными антонимами. Испытуемым предлагается охарактеризовать, используя семи-бальную шкалу оценки: а) террориста - лидера террористического движения, главные задачи которого состоят в развитии соответствующей идеологии, пропаганде и продвижении идей экстремизма и терроризма в целях вовлечения новых членов в ряды организации; б) террориста - исполнителя, члена террористического подполья, главные задачи которого состоят в участии в подготовке и совершении терактов; в) террориста-смертника (мужчину); г) террористку-смертницу (женщину).

В качестве респондентов выступили 176 человек (84 юноши и 92 девушки) в возрасте 1922 года, являющиеся студентами психологического и экономического факультетов Южного Федерального университета, расположенного в городе Ростове - на - Дону. Важно отметить, что этническая палитра Юга России самая пестрая и многообразная в стране. На небольшом

35 Квадратура смысла: французская школа анализа дискурса / Пер. с фр. и португ.; общ. ред. и вступ. ст. П. Серио ; предисл. Ю.С. Степанова. М., 1999. С. 17.

36 Седых Н.С. Современный терроризм с точки зрения информационно-психологических угроз // Национальная безопасность. 2012. № 2 (19). С. 69. пространстве проживают представители более 100 народов. Среди студентов, участвовавших в нашем исследовании 9\% респондентов, являются уроженцами г. Назрань Чеченской республики, 5\% - уроженцы Ставропольского края, 4\% Краснодарского края, 3\% прибыли на обучение из г. Владикавказа, 59\% являются коренными жителями г. Ростова-на-Дону, 20\% - уроженцы разных населённых пунктов Ростовской области.

Проведённое исследование позволило сделать ряд выводов, остановимся на некоторых их них. Интересно, что представления о чертах личности террористов-лидеров и исполнителей отражают представления о классических лидерах и исполнителях, занимающихся тем или иным видом деятельности. В частности, доминирующими характеристиками личности террориста - лидера, являются: уверенный, волевой, деятельный, конкретный, решительный, сильный, серьёзный. Вместе с тем террорист - исполнитель, характеризуется, прежде всего, как трудолюбивый, добросовестный, сосредоточенный. В то же время образ террориста-смертника, как мужчины, так и женщины выглядит «угрожающим»: враждебный(ая); решительный(ая), зависимый(ая); замкнутый(ая); угрюмый(ая); напряженный(ая); нелюдимый(ая).

Итак, очевидно, что представления о субъектах терроризма интерпретированы и структурированы. Это находит конкретное вербальное воплощение в характеристиках, которые транслируют смысловое содержание, закрепившееся в обыденном сознании, и реализуется, в том числе и в дискурсивных практиках, используемых для описания широкого круга жизненных явлений, не имеющих прямого отношения к терроризму и терактам, но определённым образом соотносимых с данным смысловым содержанием. Это, на наш взгляд, является яркой иллюстрацией того, что терроризм в настоящее время «революционирует» в новый вид глобальной войны ${ }^{37}$. Современный исследователь А.В. Мирошниченко подчёркивает, что действия террористов рассчитаны, прежде всего, «на информационно-психологический шок, воздействие которого на большие массы людей создает благоприятную обстановку для достижения террористами своих целей» ${ }^{38}$. Главные

Терроризм в современном мире. 2-ое изд. / Под ред. В.Л. Шульца; Центр исследований проблем безопасности РАН. М.: Наука, 2011. С. 10.

38 Мирошниченко А.В. Проблема комментария в информационных ресурса х в ходе акций террора // Материалы II Ро- 


\section{Социальные страсти}

цели терроризма сегодня - это информационнопсихологическое воздействие, заключающееся в изменении взглядов, мнений и других психологических явлений. Цели террористического акта достигаются путём психологического воздействия на лиц, не являющихся непосредственными жертвами насилия ${ }^{39}$. Это подтверждается, например, результатами эмпирического изучения представления о террористических актах у жителей ряда регионов РФ. Основной вывод данного исследования состоял в выделении инвариантной составляющей представлений о теракте у всех респондентов (жителей различных регионов РФ) - «страх». Выделение страха как ассоциации с террористическим актом у всей выборки испытуемых позволило исследователям заключить, что СМИ формируют единое понятийное содержание террористического акта ${ }^{40}$.

Однако, как показал проведённый нами анализ, последствия террористических проявлений не исчерпываются эмоционально-психологическими переживаниями тревоги и страха. Это последствия пролонгированного действия, которые приводят к изменению мировоззренческих ценностей, социальных убеждений, психологических установок. Негативные эмоции и чувства в связи с угрозой терроризма выступают своего рода «пусковым механизмом» для более глубоких социально-психологических и идеологических трансформаций, проявляющихся на уровне индивидуального и общественного сознания.

В заключение подчеркнём, что в соответствии с Концепцией противодействия терроризму в Российской Федерации, к основным мерам по предупреждению (профилактике) терроризма относятся информационные меры (разъяснение сущности терроризма и его общественной опасности, формирование стойкого неприятия обществом идеологии насилия, а также привлечение граждан к участию в противодействии терроризму) ${ }^{41}$. Однако наряду с этим, на

стовского молодёжного форума «Молодёжная инициатива 2011». Ростов н/Д.: изд-во ЮФУ, 2011. С. 42-44.

39 Современный политический экстремизм: понятие, истоки, причины, идеология, проблемы, организация, практика, профилактика и противодействие / Рук. авт. колл. А.-Н.3. Дибиров, Г.К. Сафаралиев. Махачкала, 2009. 640 с.

40 Тарабрина Н.В., Ворона О.А., Быховец Ю.В. Представления о теракте у населения различных регионов России // Психологический журнал. 2007. Т. 6. № 28. С. 16.

41 Российская газета от 20.10.2009 г. Федеральный выпуск №5022 (http://www.rg.ru/2009/10/20/zakon-dok.html). наш взгляд, назрела необходимость развития дискурсивных стратегий и практик информационного противодействия терроризму. Важно отметить, что дискурс важнейшая составляющая процесса коммуникации, которая в современных условиях, по мнению автора данной статьи, выступает как многомерный конструкт взаимодействия различных социальных контекстов. Соответственно дискурс, целесообразно рассматривать как способ конструирования образа мира, окружающей реальности и конкретных событий, в том числе и связанных с терроризмом. Такая позиция автора обусловлена тем, что дискурс с одной стороныкак способ упорядочивания реальности, механизм определения ценности (значения) предметов окружающего мира, может выступать в качестве средства познавательной деятельности сознания. С другой стороны, дискурс как вид речевой коммуникации, ориентированный на обсуждение и обоснование любых аспектов действий, мнений и высказываний может выступать способом воздействия на объект познания, с целью его изменения, то есть являться средством практической деятельности сознания ${ }^{42}$.

Таким образом, развитие определённых дискурсивных стратегий и практик информационного противодействия терроризму, должно быть, прежде всего, нацелено на достижение социального консенсуса. В современном мобильном мире восприятие, отношение, мнение по поводу социальных фактов и событий зависит, по наблюдениям автора, не столько от индивидуального опыта, способностей, психологического склада личности, когнитивного стиля воспринимающего, сколько от принятых в информационном пространстве образцов толкования явлений, базирующихся на конвенциональных значениях. Другими словами, нужна своего рода общественная договоренность относительно того, как будут интерпретироваться те или иные данные, полученные в процессе познания социальных явлений. В этой связи необходимо развивать инновационные социальные практики, позволяющие конкретно-историческим субъектам, используя общественные институты, организации и учреждения, конструктивно воздействовать на систему общественных отношений и жизнедеятельность людей.

42 Зайцев И.В. Социально-психологические особенности дискурсивных формаций политической идентичности: автореф. дис. ... канд. психол. наук. Ярославль, 2007. 25 с. 


\section{Психология и психотехника 8(71) • 2014}

\section{Список литературы:}

1. Андреева Г.М. Психология социального познания. М., 2004. 288 с.

2. Владимирова Т.B. К социальной природе понятия «информационная безопасность» // NB: Национальная безопасность. 2013. № 4. C. 78-95. (DOI: 10.7256/2306-0417.2013.4.596. URL: http://www.enotabene.ru/nb/article_596.html).

3. Владимирова Т.В. О едином ключе в понимании обеспечения информационной безопасности // NB: Национальная безопасность. 2014. № 2. C. 111-127. (DOI: 10.7256/2306-0417.2014.2.11811. URL: http://www.e-notabene.ru/nb/article_11811.html).

4. Дейк ван Т. Язык. Познание. Коммуникация. М., 1989. 308 с.

5. Деметрадзе М.Р. Преимущества социокультурной основы междисциплинарности социально-гуманитарных наук. Способы соответствия научно-образовательной системы стандартам информационного общества // NB: Проблемы общества и политики. 2014. № 2. C. 22-40. (DOI: 10.7256/23060158.2014.2.10736. URL: http://www.e-notabene.ru/pr/article_10736.html).

6. Клушина Н.И. Стилистика публицистического текста. М., 2008. 244 с.

7. Кожемякин Е.A. Дискурс-анализ массовой коммуникации (http://www.gmj.sfedu.ru/v2i1/v2i1_ kozhemyakin.htm).

8. Макаров М.Л. Основы теории дискурса. М., 2003. 280 с.

9. Манойло А.В. Технология реализации программы социальной адаптации военнослужащих // Национальная безопасность. 2013. № 4. C. 556-567. (DOI: 10.7256/2073-8560.2013.4.2401).

10. Мирошниченко А.В. Проблема комментария в информационных ресурса х в ходе акций террора // Материалы II Ростовского молодёжного форума «Молодёжная инициатива - 2011». Ростов н/Д.: издво ЮФУ, 2011. С. 42-44.

11. Попов Е.А. Человек, общество и наркотические средства: социальный, общеправовой и криминологический аспекты отношения // NB: Вопросы права и политики. 2012. № 1. C. 35-68. (URL: http://www.enotabene.ru/lr/article_48.html).

12. Седых Н.С. Психология терроризма: Электронный учебник. Ростов-на-Дону: ЮФУ. (Объём 700 мгб. Регистрационное свидетельство № 34730).

13. Седых Н.С. Психолого-политические особенности терроризма в условиях общества риска // NB: Проблемы общества и политики. 2013. № 3. C. 104-137. (DOI: 10.7256/2306-0158.2013.3.525. URL: http:// www.e-notabene.ru/pr/article_525.html).

14. Седых Н.С. Роль информационно-психологического воздействия в подготовке террористов-смертников // Психология и психотехника. 2013. № 10. C. 981-991. (DOI: 10.7256/2070-8955.2013.10.9377).

15. Седых Н.С. Роль массовой коммуникации в информационно-психологическом противодействии терроризму // Национальная безопасность. 2014. № 1. C. 32-49. (DOI: 10.7256/2073-8560.2014.1.9384).

16. Седых Н.С. Современный терроризм с точки зрения информационно-психологических угроз // Национальная безопасность. 2012. № 2 (19).

17. Седых Н.С. Терроризм в контексте информационно-психологических угроз современности // NB: Национальная безопасность. 2012. № 1. C. 182-212. (http://www.e-notabene.ru/nb/article_163.html).

18. Седых Н.С. Терроризм и глобальные риски современности: психолого-политический анализ // Международные отношения. 2013. № 1. C. 96-102. (DOI: 10.7256/2305-560X.2013.01.12).

19. Седых Н.С. Террористические угрозы и глобальные риски современности: психолого - политический анализ // NB: Международные отношения. 2012. № 1. C. 44-79. (URL: http://www.e-notabene.ru/ wi/article_293.html).

20. Современный политический экстремизм: понятие, истоки, причины, идеология, проблемы, организация, практика, профилактика и противодействие / Рук. авт. колл. А.-Н.З. Дибиров, Г.К. Сафаралиев. Махачкала, 2009. 640 с.

21. Тарабрина Н.В., Ворона О.А., Быховец Ю.В. Представления о теракте у населения различных регионов России // Психологический журнал. 2007. Том 6. № 28. С. 16.

22. Филипс Л.Дж., Йоргенсен М.В. Дискурс-анализ. Теория и метод. Харьков, 2004. 336 с.

23. Фромм Э. Бегство от свободы. М., 2008. 


\section{Социальные страсти}

24. Фуко М. Археология знания / пер. с фр.; общ. ред. Бр. Левченко. К., 1996. 208 с.

25. Черкасова М.Н. Речевые формы агрессии в текстах СМИ. Ростов-на-Дону, 2011. 123 с.

26. Чернов А.Ю. Качественный подход в психологическом исследовании. Волгоград, 2008. 340 с.

27. Шпаковская С.В. Достоверность современных российских СМИ, Интернета и научно-популярной литературы на примере освещения «инцидента в Фиуме» // Исторический журнал: научные исследования. 2012. № 1. С. 108-114.

28. Hall S. The Problem of Ideology-Marxism Without Guarantees // Journal of Communication Inquiry. 1986. Vol. 10. № 2.

29. Thompson John B. Ideology and Modern Culture. Critical Social Theory in the Era of Mass Communication. Oxford: Polity Press, 1990. P. 56-66.

30. Wagner W. Queries about social representation and construction // Journal for the theory of social behaviour. 1996. V. 26. № 2. P. 95-120.

\section{References (transliteration):}

1. Andreeva G.M. Psikhologiya sotsial'nogo poznaniya. M., 2004. 288 s.

2. Vladimirova T.V. K sotsial'noi prirode ponyatiya «informatsionnaya bezopasnost'» // NB: Natsional'naya bezopasnost'. 2013. № 4. S. 78-95. (DOI: 10.7256/2306-0417.2013.4.596. URL: http://www.e-notabene.ru/ nb/article_596.html).

3. Vladimirova T.V. O edinom klyuche $\mathrm{v}$ ponimanii obespecheniya informatsionnoi bezopasnosti // NB: Natsional'naya bezopasnost'. 2014. № 2. S. 111-127. (DOI: 10.7256/2306-0417.2014.2.11811. URL: http:// www.e-notabene.ru/nb/article_11811.html).

4. $\quad$ Deik van T. Yazyk. Poznanie. Kommunikatsiya. M., 1989. 308 s.

5. Demetradze M.R. Preimushchestva sotsiokul'turnoi osnovy mezhdistsiplinarnosti sotsial'no-gumanitarnykh nauk. Sposoby sootvetstviya nauchno-obrazovatel'noi sistemy standartam informatsionnogo obshchestva // NB: Problemy obshchestva i politiki. 2014. № 2. S. 22-40. (DOI: 10.7256/2306-0158.2014.2.10736. URL: http://www.e-notabene.ru/pr/article_10736.html).

6. Klushina N.I. Stilistika publitsisticheskogo teksta. M., 2008. 244 s.

7. Kozhemyakin E.A. Diskurs-analiz massovoi kommunikatsii (URL: http://www.gmj.sfedu.ru/v2i1/v2i1_ kozhemyakin.htm).

8. Makarov M.L. Osnovy teorii diskursa. M., 2003. 280 s.

9. Manoilo A.V.Tekhnologiya realizatsii programmy sotsial'noi adaptatsii voennosluzhashchikh // Natsional'naya bezopasnost'. 2013. № 4. S. 556-567. (DOI: 10.7256/2073-8560.2013.4.2401).

10. Miroshnichenko A.V. Problema kommentariya $\mathrm{v}$ informatsionnykh resursa kh $\mathrm{v}$ khode aktsii terrora // Materialy II Rostovskogo molodezhnogo foruma «Molodezhnaya initsiativa - 2011». Rostov-na-Donu: izdvo YuFU, 2011. S. 42-44.

11. Popov E.A. Chelovek, obshchestvo i narkoticheskie sredstva: sotsial'nyi, obshchepravovoi i kriminologicheskii aspekty otnosheniya // NB: Voprosy prava i politiki. 2012. № 1. S. 35-68. (URL: http://www.e-notabene.ru/ lr/article_48.html).

12. Sedykh N.S. Psikhologiya terrorizma: Elektronnyi uchebnik. Rostov-na-Donu: YuFU. (Ob"em 700 mgb. Registratsionnoe svidetel'stvo № 34730).

13. Sedykh N.S. Psikhologo-politicheskie osobennosti terrorizma v usloviyakh obshchestva riska // NB: Problemy obshchestva i politiki. 2013. № 3. S. 104-137. (DOI: 10.7256/2306-0158.2013.3.525. URL: http://www.enotabene.ru/pr/article_525.html).

14. Sedykh N.S. Rol' informatsionno-psikhologicheskogo vozdeistviya v podgotovke terroristov-smertniov // Psikhologiya i psikhotekhnika. 2013. № 10. S. 981-991. (DOI: 10.7256/2070-8955.2013.10.9377).

15. Sedykh N.S. Rol' massovoi kommunikatsii v informatsionno-psikhologicheskom protivodeistvii terrorizmu // Natsional'naya bezopasnost'. 2014. № 1. S. 32-49. (DOI: 10.7256/2073-8560.2014.1.9384).

16. Sedykh N.S. Sovremennyi terrorizm s tochki zreniya informatsionno-psikhologicheskikh ugroz // Natsional'naya bezopasnost'. 2012. № 2 (19). 


\section{Психология и психотехника 8(71) • 2014}

17. Sedykh N.S. Terrorizm $\mathrm{v}$ kontekste informatsionno-psikhologicheskikh ugroz sovremennosti // NB: Natsional'naya bezopasnost'. 2012. № 1. S. 182-212. (URL: http://www.e-notabene.ru/nb/article_163.html).

18. Sedykh N.S. Terrorizm i global'nye riski sovremennosti: psikhologo-politicheskii analiz // Mezhdunarodnye otnosheniya. 2013. № 1. C. 96-102. (DOI: 10.7256/2305-560X.2013.01.12).

19. Sedykh N.S. Terroristicheskie ugrozy i global'nye riski sovremennosti: psikhologo - politicheskii analiz // NB: Mezhdunarodnye otnosheniya. 2012. № 1. S. 44-79. (URL: http://www.e-notabene.ru/wi/article_293. html).

20. Sovremennyi politicheskii ekstremizm: ponyatie, istoki, prichiny, ideologiya, problemy, organizatsiya, praktika, profilaktika i protivodeistvie / Ruk. avt. koll. A.-N.Z. Dibirov, G.K. Safaraliev. Makhachkala, 2009. $640 \mathrm{~s}$.

21. Tarabrina N.V., Vorona O.A., Bykhovets Yu.V. Predstavleniya o terakte u naseleniya razlichnykh regionov Rossii // Psikhologicheskii zhurnal. 2007. T. 6. № 28.

22. Filips L.Dzh., Iorgensen M.V. Diskurs-analiz. Teoriya i metod. Khar'kov, 2004. 336 s.

23. Fromm E. Begstvo t svobody. M., 2008.

24. Fuko M. Arkheologiya znaniya / per. s fr.; obshch. red. Br. Levchenko. K., 1996. 208 s.

25. Cherkasova M.N. Rechevye formy agressii v tekstakh SMI. Rostov-na-Donu, 2011. $123 \mathrm{~s}$.

26. Chernov A.Yu. Kachestvennyi podkhod v psikhologicheskom issledovanii. Volgograd, 2008. $340 \mathrm{~s}$.

27. Shpakovskaya S.V. Dostovernost' sovremennykh rossiiskikh SMI, Interneta i nauchno-populyarnoi literatury na primere osveshcheniya «intsidenta v Fiume» // Istoricheskii zhurnal: nauchnye issledovaniya. 2012. № 1. S. 108-114.

28. Hall S. The Problem of Ideology-Marxism Without Guarantees // Journal of Communication Inquiry. 1986. Vol. 10. № 2.

29. Thompson John B. Ideology and Modern Culture. Critical Social Theory in the Era of Mass Communication. Oxford: Polity Press, 1990. P. 56-66.

30. Wagner W. Queries about social representation and construction // Journal for the theory of social behaviour. 1996. V. 26. № 2. P. 95-120. 